\title{
支障物撤去型掘進工法における地盤改良用 二液混合噴流の地盤掘削特性に関する研究
}

\author{
神山 守 1 ・小泉 淳 2 ・磯部 隆寿 3 ・田中 雅彦 4 ・志村 洋平 5 \\ 1正会員 東京都下水道局 流域下水道本部（干190-0022 東京都立川市錦町 1-7-26） \\ E-mail: Mamoru_Kamiyama@member.metro.tokyo.jp \\ 2 正会員 早稲田大学教授 理工学術院（干169-8555 東京都新宿区大久保三丁目 4 番 1 号) \\ E-mail: koizumi@waseda.jp \\ 3非会員＼cjkstart鹿島建設株式会社＼cjkstart技術研究所（干182-0036 東京都調布市飛田給 2-19-1） \\ E-mail: isobeta@kajima.com \\ 4非会員 東京都下水道サービス株式会社 技術部（テ100-0004 東京都千代田区大手町二丁目 1 番 1 号） \\ E-mail: masahiko-tanaka@tgs-sw.co.jp \\ 5 非会員Ｎ.JET エンジニアリング株式会社＼cjkstart企画営業部（†103-0021 東京都中央区日本橋石町 3-2-7） \\ E-mail: shimura@n-jet.co.jp
}

\begin{abstract}
本工法は，シールド工法等の掘進機に二液混合噴流を用いた超高圧噴射システムを搭載し，地中支障物 の切断・除去や地盤改良などを行う工法として多くの施工実績がある. 一方，噴流による周辺地盤への影 響は，実験的研究で確認しているものの，近接構造物への影響を明示寸るには至っていない.

本論文は, 二液混合噴流の地盤掘削特性を, 噴流の動圧の測定, 模擬地盤の掘削過程の観測および FVM 解析により明らかにし，その影響範囲について数值的な根拠を示したものである. 本研究の結果, 噴流の動圧はノズルからの噴出直後で近接構造物を損傷する恐れがないこと，FVM 解析によって地盤の 掘削過程および掘削領域内の流動特性をよい精度でシミュレートできることなどが分かった.
\end{abstract}

Key Words: pipe-jacking method, shield method, waterjet, fluid, excavation, soil stabilization

\section{1. はじめに}

本工法は，推進工法またはシールド工法の掘進機に， 二液混合噴流（超高圧ジェットと低圧ジェットを混合し て噴射する方式）を用いた超高圧噴射システムを搭載し， 地中に残置された鋼矢板やコンクリートパイルなどの支 障物を切断・除去し，また，地盤改良などを行う工法と して多くの施工実績があり，その適用は拡大してきてい る. 本工法の施工方法や切断性能，地盤改良の精度およ び改良範用，周辺地盤への影響などは，これまでに多く の実験によって検証されており，それらは設計・施工報

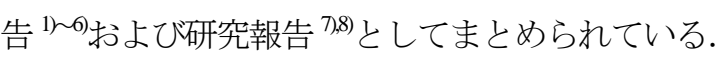

一方，二液混合噴流の動圧分布やその減衰などの地盤 中の挙動は，施工中に計測することが困難なことから， 近接構造物などに与えるジェット噴流の影響や範囲を明 らかにするには至っていない.

本論文は，圧力容器を用いた水中噴射実験により二液 混合噴流の動圧分布を測定し，飽和地盤中における地盤
改良時の影響範囲について考察したものである.

地盤掘削実験は, 圧力容器中に模擬地盤を作成し, そ の掘削過程を観測するものであり，これにより二液混合 噴流の動圧と地盤掘削の進行状況を把握した.

また，水中噴流に関する FVM 解析を実施し，実験結 果と比較検討することでその影響や範囲を検証した。

\section{2. 工法の概要}

\section{(1) 開発の背景}

推進工法またはシールド工法では，立坑からの発進時 や立坑一の到達時，急曲線の施工時，また，とくに重要 な構造物附近を通過するとき，あるいは支障物に遭遇し たときなどに，必要に応じて地盤改良を実施している. これらの場合には，地盤改良は止水性に加えてその強度 も要求されることから，セメント系の材料を用いた地盤 改良か，または，凍結工法が用いられる，既存のセメン 
卜系の地盤改良工法の多くは，鉛直下向きの施工を前提 としており，地上からの施工に限定されるため，その適 用が困難な場合も少なくない，また，凍結工法は，シー ルド機内からの施工が可能であるが工期や費用の観点か らみると負担が大きい. 水平地盤改良が可能なジェット グラウト工法も開発されているが，改良範囲の拡大のた めにはエアージェットによるアシストが必要となる。 と くに，シールド掘進機の上半の地盤を改良する場合はエ アーだまりによる空洞の発生が懸念される.

以上のことから，シールド掘進機に装備が可能で，水 平のみならず上方への地盤改良を可能とする二液混合噴 流を用いた超高圧噴射システムを開発した.

二液混合噴流は，ノズルから噴射する直前に二種類の 液体を混合するもので，それぞれの液体の種類および圧 力，流量を噴射の目的に応じて適切に設定することによ り，その効果を最大化することが可能である.

\section{(2) 本システムの構成と特徵}

図-1 は，超高圧噴射システムに用いる二液混合ノズ ルの構造などを示したものである。二液混合ノズルは, ジェットライン（以下 WJ ラインと呼ぶ）から超高圧の 珪酸ナトリウム溶液が，アブレシブライン（以下 $\mathrm{AJ}$ ラ インと呼ぶ）から低圧の液体がそれぞれ供給され，ミキ シング室内で混合した液体をアブレシブノズル（以下 AJ ノズルと呼ぶ）から二液混合噴流として噴射するも のである.

二液混合ノズルは，図-2 に示すように，地盤改良用 ノズルと切断用ノズルから構成されており, 掘進機の前 面に装着される. 二液混合ノズルの AJ ラインに供給さ れる液体は，地盤改良を行う場合にはセメントミルクで あり，地中支障物の切断を行う場合には研磨材と硬化剂 を混合した AJ スラリーである. いずれの場合も混合し た流体は珪酸ナトリウムと反応し早期にゲル化し，掘削 空間は非流動性の物質で充填されることから，地盤の変 状が抑止される.

ノズルの移動は，掘削機のカッタヘッドの微速回転に よるほか, 必要に応じてカッタヘッドの半径方向に移動 可能な移動システムを用いて行う.

\section{3. ノズル内の混合過程のモデル化とその検証}

\section{（1）運動量保存則による混合噴流の噴出速度}

本工法による地盤改良では，AJラインから $1 \mathrm{MPa}$ 程度 の圧力でセメントミルクを圧送する.

この液体は WJ ラインからの高速噴流とミキシング室 内および $\mathrm{AJ}$ ノズル内で混合される. 二液混合ノズルの $\mathrm{WJ}$ ノズルの出口から $\mathrm{AJ}$ ノズルの出口までの距離は, 約

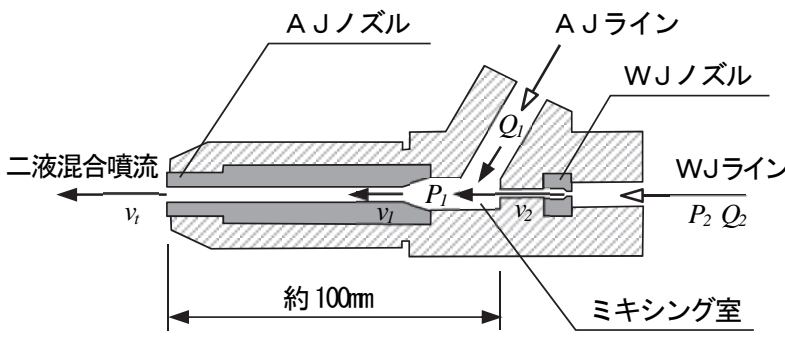

図-1 二液混合ノズルの構造と混合過程

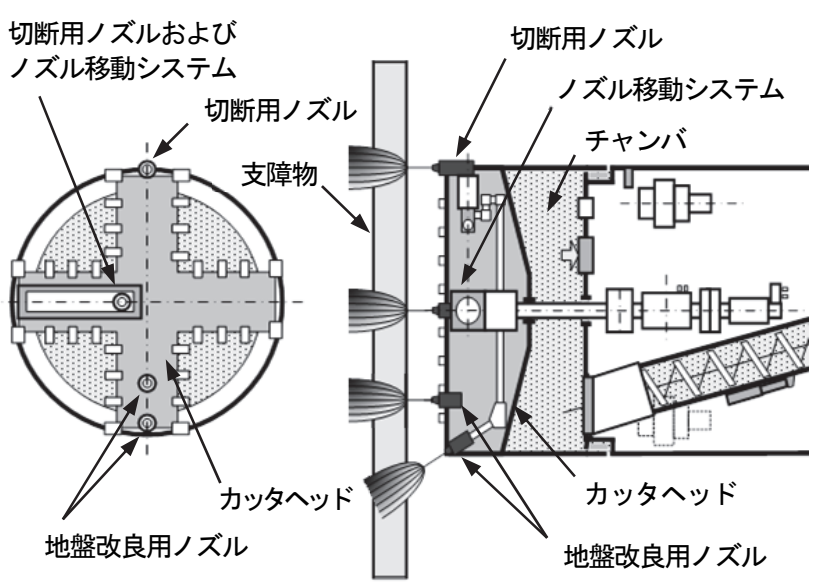

図-2＼cjkstart掘進機への超高圧噴射ノズル装着概要図

100mm であり, 文献 8)に示したウォータージェット

（WJ）の水中噴射実験の結果から，噴流軸中心部の高 速噴流が周囲の水に運動量を与え，一体化した流れとな るには十分の長さと判断される.

このことから, WJ ラインの運動量と AJラインの運動 量は加算され，一体化した噴流となり $\mathrm{AJ}$ ノズルから噴 出すると想定できる.

二液混合ノズルからの混合噴流の噴出速度は, 前述し たように噴流が一体化されると仮定すれば，以下の手順 で算定することができる.

一般に気中に噴射された自由噴流においては大気圧及 びノズル内壁摩擦損失を無視すると, 噴射圧力 $P[\mathrm{~Pa}]$, 噴流平均速度 $v[\mathrm{~m} / \mathrm{s}]$ と質量流量 $Q[\mathrm{~kg} / \mathrm{s}]$ および噴流の運 動量流束 $M\left[\mathrm{~kg} \cdot \mathrm{m} / \mathrm{s}^{2}\right]$ の間には以下の関係がある.

$$
\begin{gathered}
P=\frac{\rho}{2} \cdot v^{2} \\
M=Q \cdot v=Q \cdot \sqrt{\frac{2 P}{\rho}}
\end{gathered}
$$

ここで, $\rho$ は流体の密度 $\left[\mathrm{kg} / \mathrm{m}^{3}\right]$ である.

AJ ラインでは流量計で測定した体積流量 $Q_{1}{ }^{\prime}\left[\mathrm{m}^{3} / \mathrm{s}\right]$ と $\mathrm{AJ}$ ノズルの有効断面積 $A_{1}\left[\mathrm{~m}^{2}\right]$ から式(3)で流速を算出し, 
単位時間あたりの運動量流束を求める.

$$
v_{1}=\frac{Q_{1}^{\prime}}{A_{1}} \quad, \quad M_{1}=v_{1} \cdot Q_{1}^{\prime} \cdot \rho_{1}=v_{1} \cdot Q_{1}
$$

AJ ラインからミキシング室に流入した流れは複雑で 三次元流れとして取扱う必要があるが，最終的には AJ ノズルのテーパー部で加速され，直線部では $v_{1}$ という 速度を持つ一次元流れとなる. 式(3)は AJ ノズル直線部 の一次元流れを記述しており，速度も運動量もスカラー で表記した。

WJ ラインの測定は，超高圧で使用可能な流量計の調 達が困難なことから式(4)に示すように，噴射圧力 $P_{2}$ と WJ ノズルの断面積 $A_{2}\left[\mathrm{~m}^{2}\right]$ から体積流量 $Q_{2}{ }^{\prime}\left[\mathrm{m}^{3} / \mathrm{s}\right]$ を求め, 式(5)で運動量流束 $M_{2}$ を求める.

$$
\begin{aligned}
& Q_{2}{ }^{\prime}=A_{2} \cdot v_{2}=A_{2} \sqrt{\frac{2 P_{2}}{\rho_{2}}} \\
& M_{2}=v_{2} \cdot Q_{2}{ }^{\prime} \cdot \rho_{2}=v_{2} \cdot Q_{2}
\end{aligned}
$$

WJ ノズルから噴出する流れはミキシング室に流入し た時点から AJ ラインからの流れと相互作用し運動量の 伝達が生じるが，半径方向の速度成分は微少で概ね一次 元流れと見なせる. よって, AJ ノズルから噴出する混 合噴流の運動量流束 $M_{t}$ は，式(6)に示すように $M_{1}$ と $M_{2}$ のスカラー和で求められ，これを合計流量で除せば，式 (7)に示すように混合噴流速度 $v_{t}$ が得られる.

$$
\begin{gathered}
M_{t}=M_{1}+M_{2} \\
v_{t}=\frac{M_{t}}{Q_{1}+Q_{2}}
\end{gathered}
$$

\section{(2) 算出された流速の検証}

算出された流速の妥当性を確認するため, 高速度ビデ オを用いて噴流を撮影し，実際の流速を測定した。噴流 の速度は，図-3 に示すように遮へい板により瞬間的に 遮断し, 噴流の後尾の位置変化を 1000 フレーム/s のフ レーム間の移動量から求めた. WJ ラインの噴射圧力は, 噴流の後尾の移動量がフレーム内に納まるように $50 \mathrm{MPa}$ に設定した.

その結果は表-1 に示すとおりである。また，写真-1 および写真-2 は, 閃光時間 $2 \mu \mathrm{s}$ 以下のフラッシュで撮影 した静止画像である. 表-1 からわかるように，AJ ライ ン単独の噴射の場合も，超高圧混合噴射の場合も，実測 した噴流の速度は，運動量保存則から算出した噴流速度 と概ね一致しており，運動量保存則が成立することを示 している.

\section{4. 水中における噴流の動圧の測定}

文献 8) には動圧の測定についての詳細が報告されて いる.ここでは，本研究で行った動圧の測定実験の方法 とその結果の概要を示すことにする.

\section{(1) 実験方法}

\section{a) 圧力容器}

写真-3 は圧力容器の外観を示している. 圧力容器に は，様々なスタンドオフ距離 SD（二液混合ノズル出口 から動圧測定位置までの距離）における噴流状態を観測 するため，観測用空と測定用空を 330 mm ピッチにそれ ぞれ 6 か所装備している. 圧力容器は水深 $50 \mathrm{~m}$ までの 環境を再現できるように耐圧 $0.5 \mathrm{MPa}$ とし，圧力は容器 の上部フランジに取り付けた圧力調整弁によりコントロ 一ルする. ノズルの装着部は，写真-4 に示すように， 掘進機の面盤とチャンバーを模擬して隔壁で仕切るよう にしてある。

\begin{tabular}{|c|c|c|c|c|}
\hline \multicolumn{3}{|c|}{ 実 験 項 目 } & 単独噴射 & 混合噴射 \\
\hline \multirow{5}{*}{ [1]AJライン } & 噴射圧力 & $\mathrm{MPa}$ & 0.2 & 1.0 \\
\hline & ノズル径 & $\mathrm{mm}$ & 6.0 & 6.0 \\
\hline & 質量流量 & $\mathrm{kg} / \mathrm{s}$ & 0.5 & 1.1 \\
\hline & 噴流速度 & $\mathrm{m} / \mathrm{s}$ & 18.1 & 40.5 \\
\hline & 運動量流束 & $\mathrm{kg} \cdot \mathrm{m} / \mathrm{s}^{2}$ & 9.3 & 46.3 \\
\hline \multirow{5}{*}{ [2]WJライン } & 噴射圧力 & $\mathrm{MPa}$ & & 50.0 \\
\hline & ノズル径 & $\mathrm{mm}$ & & 1.35 \\
\hline & 質量流量 & $\mathrm{kg} / \mathrm{s}$ & & 25.5 \\
\hline & 噴流速度 & $\mathrm{m} / \mathrm{s}$ & & 316.2 \\
\hline & 運動量流束 & $\mathrm{kg} \cdot \mathrm{m} / \mathrm{s}^{2}$ & & 134.6 \\
\hline$[1]+[2]$ & 運動量流束 & $\mathrm{kg} \cdot \mathrm{m} / \mathrm{s}^{2}$ & - & 180.9 \\
\hline \multicolumn{2}{|c|}{ 混合噴流の算定速度 } & $\mathrm{m} / \mathrm{s}$ & 18.1 & 115.2 \\
\hline \multirow{2}{*}{ 画像解析 } & 移動量/1ms & $\mathrm{mm}$ & 16.0 & 120.0 \\
\hline & 噴流の実測流速 & $\mathrm{m} / \mathrm{s}$ & 16.0 & 120.0 \\
\hline
\end{tabular}
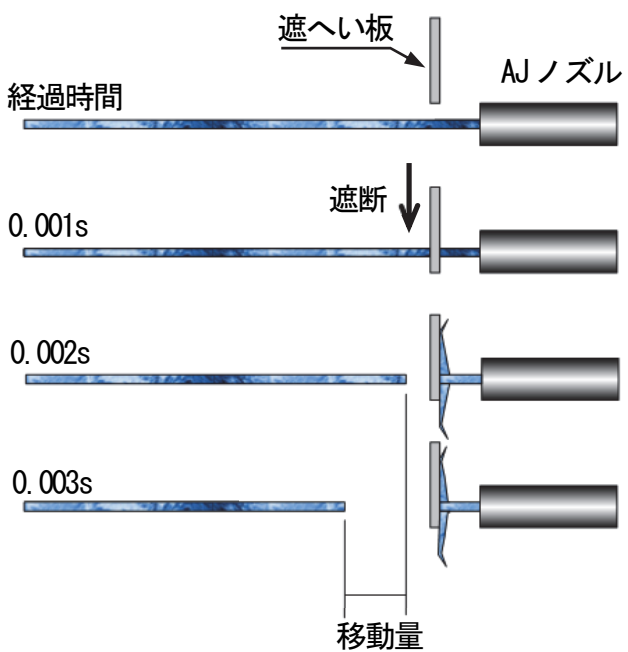

図-3＼cjkstart画像による流速測定方法概要図

表-1 算定流速と実測流速の比較 


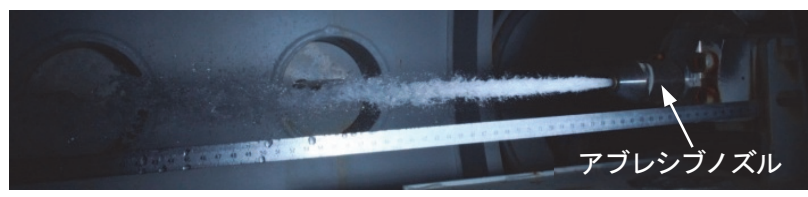

写真-1 AJライン単独噴射状況

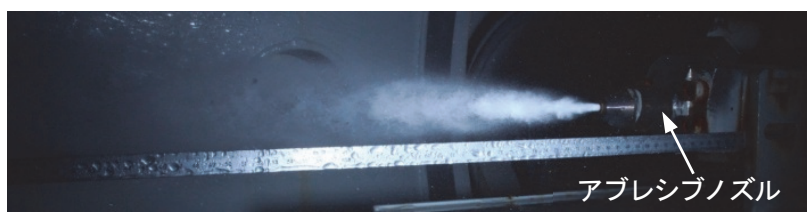

写真-2 2 液混合噴射状況

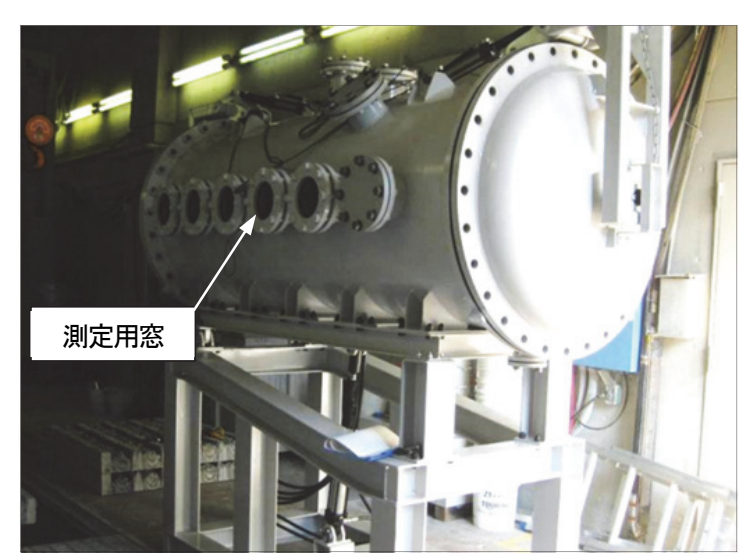

写真-3 圧力容器の外観

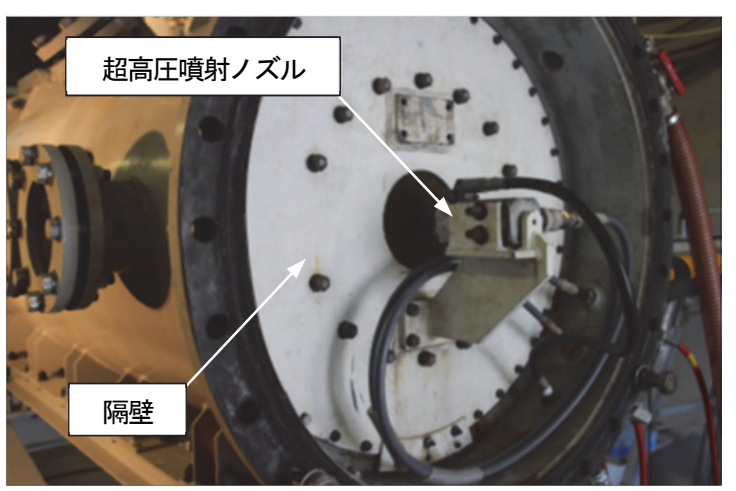

写真-4 圧力容器内のノズル装着部と隔壁

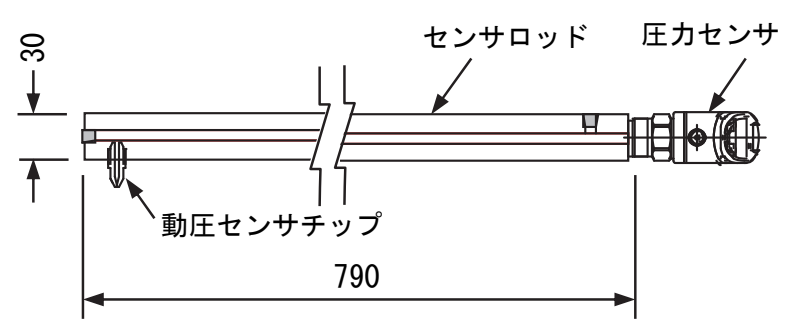

図-4 動圧測定センサ

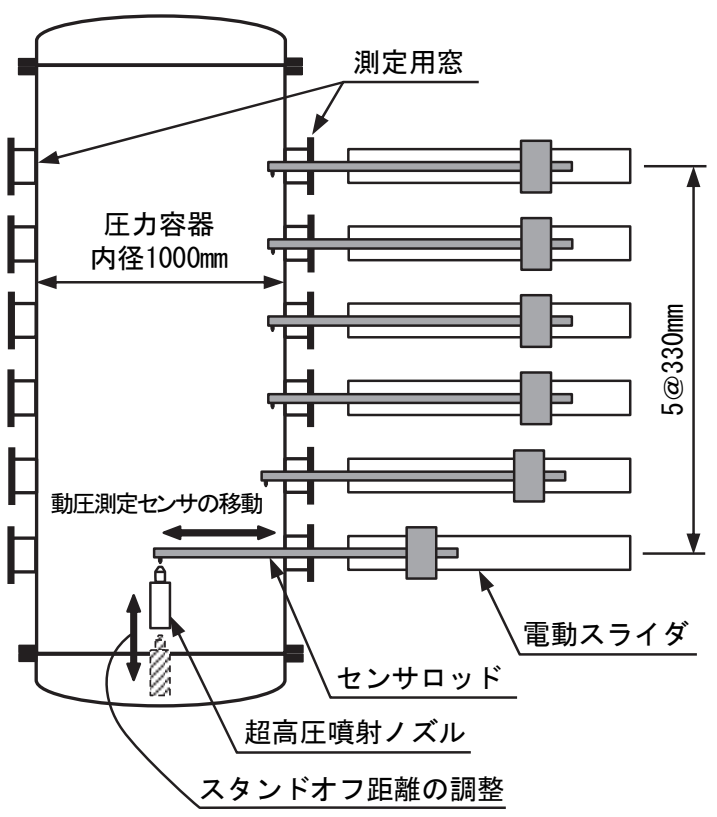

図-5 動圧測定センサの配置状況

\section{b）動圧測定のセンサ}

超高圧ジェット噴流の動圧は，噴流の半径方向に分布 する.このため, 図-4 に示すピト一管式のセンサを, 所定の速度で噴流軸と直交する方向に移動できるような 移動装置を製作し，図-5 に示すように圧力容器の測定 用空に装着した，噴流軸と直行する方向の移動は，電動 スライダで，スタンドオフ距離の調整は，移動装置の切 り替えとノズル位置の微調整で実施した。

\section{c) 実験条件}

実験は超高圧噴射システムを用いた地盤改良を想定し， SD と容器内の圧力とをパラメータとして行った. この 地盤改良システムの稼働時の標準仕様は，WJ ラインの 噴射圧力が最大 $245 \mathrm{MPa}$ ，噴射流量が $55 \mathrm{~L} / \mathrm{min}$ で，AJ ラ インが流量 70L/min である. 実験では，WJ ラインの圧 力を実験用ポンプの最大圧力である 200MPaに, AJ ライ ンの噴射流量を 70L/min に固定した。

\section{（2）実験結果}

a) 動圧分布

図-6 は，容器内の圧力を水深 $0.5 \mathrm{~m}$ 相当に設定して噴 射したときの動圧分布をそれぞれ SD ごとに示したもの である．この図をみると $\mathrm{SD}=2 \mathrm{~mm}$ では動圧が高く立ち 上がり測定幅（噴流幅）が狭いが，SD が 50mm， $100 \mathrm{~mm}, 200 \mathrm{~mm}$ と大きくなるほど噴流幅が広くなって いることがわかる。これは噴流がもつ運動量が周囲の水 に遷移したためと考えられる. 動圧の減少は急激で, $\mathrm{SD}=2 \mathrm{~mm}$ の最大動圧に比べて $\mathrm{SD}=100 \mathrm{~mm}$ では約 1/5 に, $\mathrm{SD}=200 \mathrm{~mm}$ では $1 / 10$ 以下になっている. 

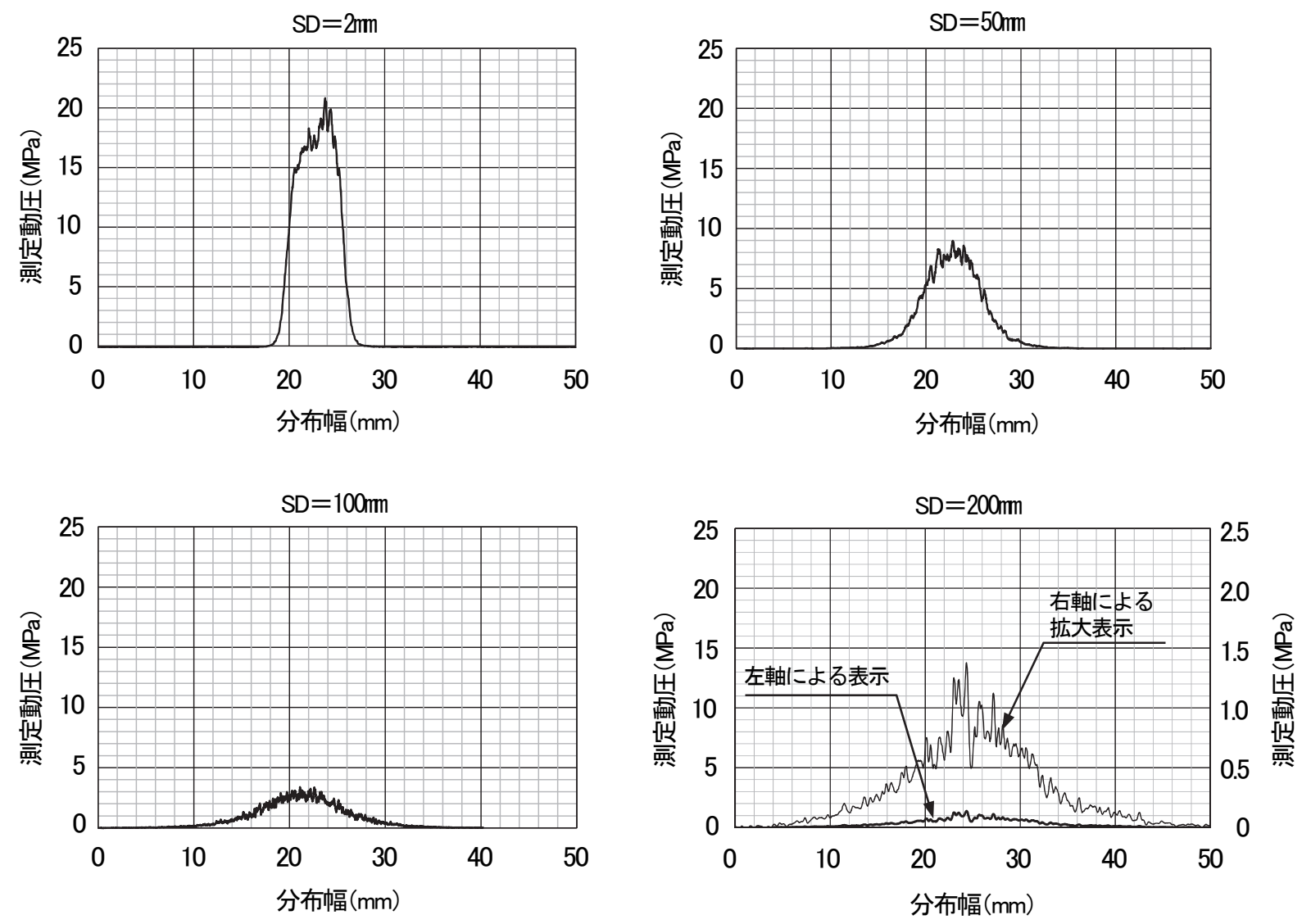

図-6＼cjkstart動圧スタンドオフ距離一動圧分布測定結果

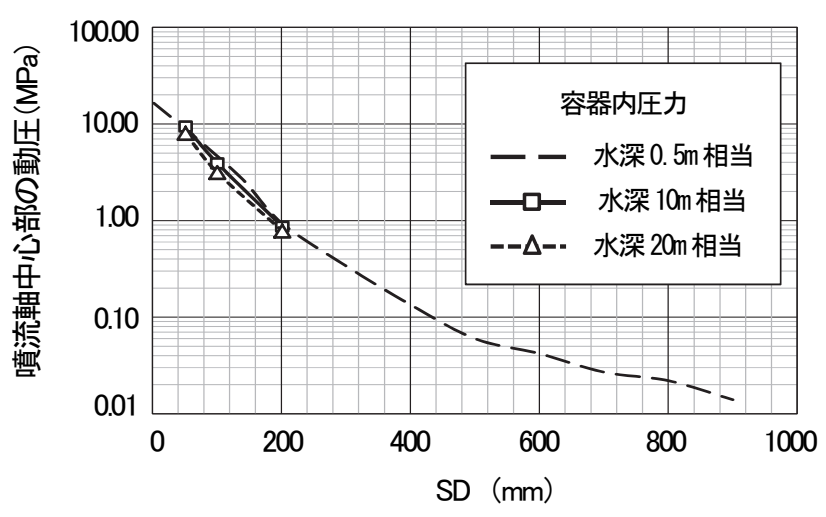

図-7 噴流軸中心部の動圧測定結果

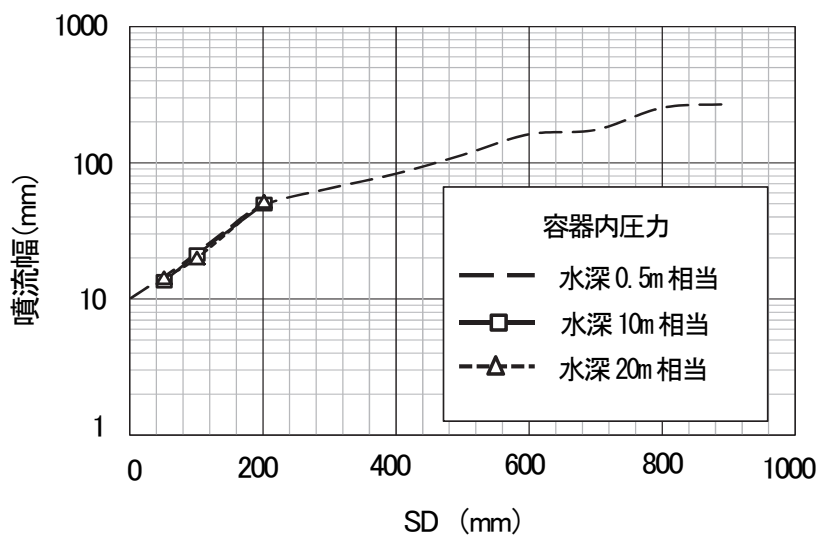

図-8＼cjkstart噴流幅の測定結果

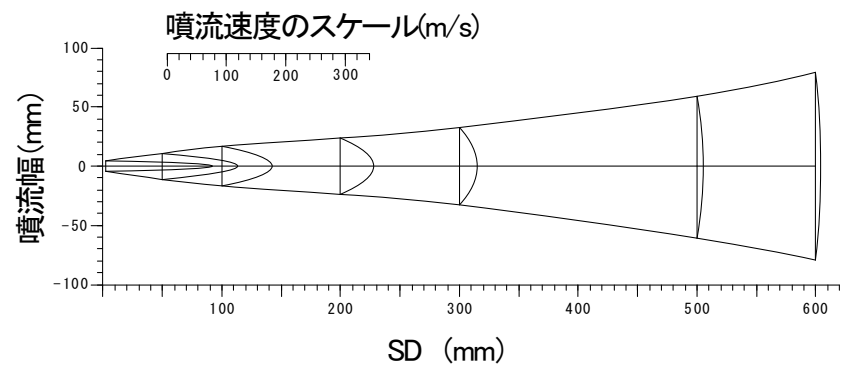

図-9噴流幅拡大の模式図

b）噴流軸中心部の動圧と噴流幅

図-7 および図-8 は，水深 $0.5 \mathrm{~m}$ 相当， $10 \mathrm{~m}$ 相当， $20 \mathrm{~m}$ 相当の 3 ケースで容器内の圧力を調整して, SD と噴流 軸中心部の動圧および噴流幅との関係を示したものであ る.また，動圧分布や噴流幅の変化を視覚的に把握する ため, SD と噴流幅を同一のスケールとした模式困を図9 に示す. 図の分布は，実験で得られた幅と最大值を二 次曲線で結んだ. SD が大きい位置の分布を識別可能と するため動圧分布に変えて速度分布を用いた.

軸中心部の動圧は SD が大きくなるとともに減衰し, $\mathrm{SD}=400 \mathrm{~mm}$ では $130 \mathrm{kPa}, \mathrm{SD}=800 \mathrm{~mm}$ では $20 \mathrm{kPa}$ まで低 下した.この值は比較的軟弱な粘性土の一軸圧縮強さ以 下に相当する. 一方, 水深 (容器内の圧力) が増加して も軸中心部の動圧や噴流幅には変化が見られず，どの水 
深でも同様の噴流構造となっていることがわかる.

すなわち，超高圧噴射システムを用いた地盤改良では， 被圧の大小は地盤の掘削能力に影響しないことが確認で きる．また，噴流幅は，SD が大きくなるほど周囲の水 を取り込み拡大した. $\mathrm{SD}=900 \mathrm{~mm}$ の場合の噴流幅は, ノズル出口付近の幅の約 25 倍になった. 結果として, 高速でかつ小径の超高圧二液混合噴流は, SD の増加と ともに低速て噴流径の大きな流れに変化していくことが 確認できた.

\section{(3) まとめ}

以上の検討の結果，本超高圧噴射システムを用いた地 盤改良では，噴流が AJ ノズルから噴出した時点では， 一般の噴射摚拌式地盤改良工法の技術資料 ${ }^{9}$ に記載され ている噴射圧力（18MPa 以上）と同程度の圧力となって おり, 通常 18〜 100 N/ $/ \mathrm{mm}^{2}$ 程度の圧縮強度とされる ${ }^{10)}$ コ ンクリート構造物に損傷を与える圧力レベル以下となっ ていることがわかった．また，動圧はノズルからの距離 が長くなればなるほど大きく低下し，距離が 1000mm の 位置では, 粘性土地盤の掘削限界に至る. 寸なわち, 本 超高圧噴射システムを用いた地盤改良では, 近接構造物 を損傷する可能性は極めて低いことが確認できた.

\section{5. 水中における噴流の流動特性の FVM 解析}

水中における動圧の計測実験で得られた測定值の妥当 性を検証するとともに，掘削空間における噴流の流動状 態および掘削空間の内壁に作用する力を把握するために FVM 解析を実施した。

\section{(1) 定常解析モデル}

解析には 2 次元軸対称モデルを用いた. 解析条件は, 表-2 に示すとおりである. 解析は掘削の進行にともな う空間の拡大を模擬するために, 解析領域の直径 $D$ お よび長さ $L$ を変化させて行った.

図-10 はメッシュ分割の一例を示したものであり，同 図には解析領域を便宜上区分け（以下ゾーンと呼ぶ）を して示してある.ゾーンは後述する地盤掘削実験の容器 の形状を考慮して定めた. 図で axis は噴流軸で, これを 中心に軸対象としている. wall-side は容器の内壁, wallend は容器の先端の境界である. wall-inner の左はチャン バを模擬しており，上部に排出口として outlet を設けた. また, Inletはノズルの先端を表し axis 上の wall-inner との 交点に設置した。ノズルの周辺には直径 $200 \mathrm{~mm}$ の通水 口を設けている. inlet は半径 $5 \mathrm{~mm}$ の速度境界とし, 実 測で得られた $\mathrm{SD}=2 \mathrm{~mm}$ の動圧分布を速度分布に変換し て与え, 一方, outlet は圧力境界として大気圧を与えた.
表-2 解析条件

\begin{tabular}{|l|l|l|l|l|l|l|l|}
\hline 解析コード & \multicolumn{7}{|c|}{ ANSYS FLUENT 定常解析 } \\
\hline 座標 & \multicolumn{7}{|c|}{ 2 次元軸対称 } \\
\hline 乱流モデル & \multicolumn{7}{|c|}{ Realizable kepsilon+Enhanced Wall Treatment } \\
\hline 解析形状 & \multicolumn{8}{|c|}{$L \mathrm{~mm}$} \\
\hline 直径 $600 \mathrm{~mm}$ & 600 & 800 & 1,000 & 1,200 & 1,400 & 1,600 & \\
\hline 直径 $800 \mathrm{~mm}$ & 600 & 800 & 1,000 & 1,200 & 1,400 & 1,600 & \\
\hline 直径 $1000 \mathrm{~mm}$ & 600 & 800 & 1,000 & 1,200 & 1,400 & 1,600 & 1,800 \\
\hline
\end{tabular}

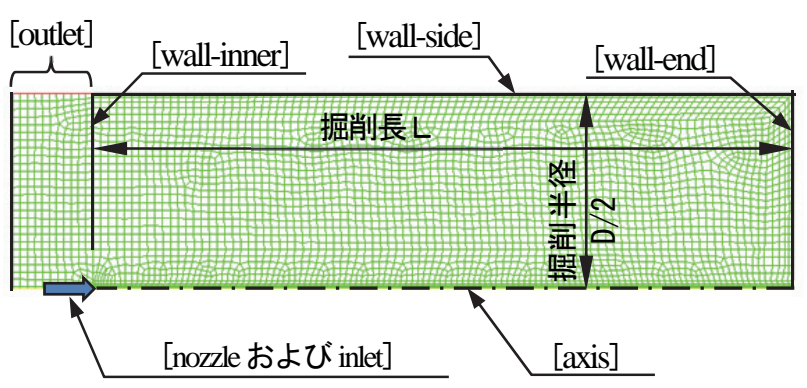

図-10 メッシュ分割と解析領域

混合ノズルの噴射条件は，動圧測定と同様に，WJ ラ インの圧力を $200 \mathrm{MPa}$ ，AJ ラインの噴射流量を $70 \mathrm{~L} / \mathrm{min}$ に固定した.

\section{（2） 解析結果}

図-11 は動圧分布の実測值と解析值との関係の一例を 示したものである. 図-11 の上図は inlet の入力值を示し ている. 図-12 は SD の増加にともなう動圧分布の中央 值と分布幅の変化を示している. これらの図から解析值 は動圧分布形状, SD の増加にともなう中心動圧と分布 幅の変化が，ともに実測值を精度よく表しており，解析 值と実測値双方の妥当性が確認できる.

掘削の進行にともなう噴流の流動状態の変化を模擬す るため, wall-end の位置を移動させて解析した結果を図13 および図-14 に示す. 図-13 は inlet を始点とし, 要素 毎にベクトルの方向のみを考慮して速度ベクトルを接合 した線を描いたもので，ノズルから噴出した流体の軌跡 を示している. 速度は色で表示している. 接合要素数を 10000 に設定したため相当数の循環流れを表している.

図-14 は容器径 800mm の場合の速度ベクトルを示して いる. これらの図から，噴流は wall-end に到達すると半 径方向の流れとなり, wall-side に向かい, さらにその流 れは wall-side に沿い wall-inner 方向に戻る. 戻った流れは 一部が通水口から outlet に排出され, 残りはノズルから 高速噴流に巻き込まれることがわかる．境界の壁に作用 する力は, 壁に垂直の速度成分によるよどみ点の圧力

（せき止め圧）と壁に平行な流れによるせん断力（掃流 力）であるが, wall-end の中央部と wall-side の wall-end 近 

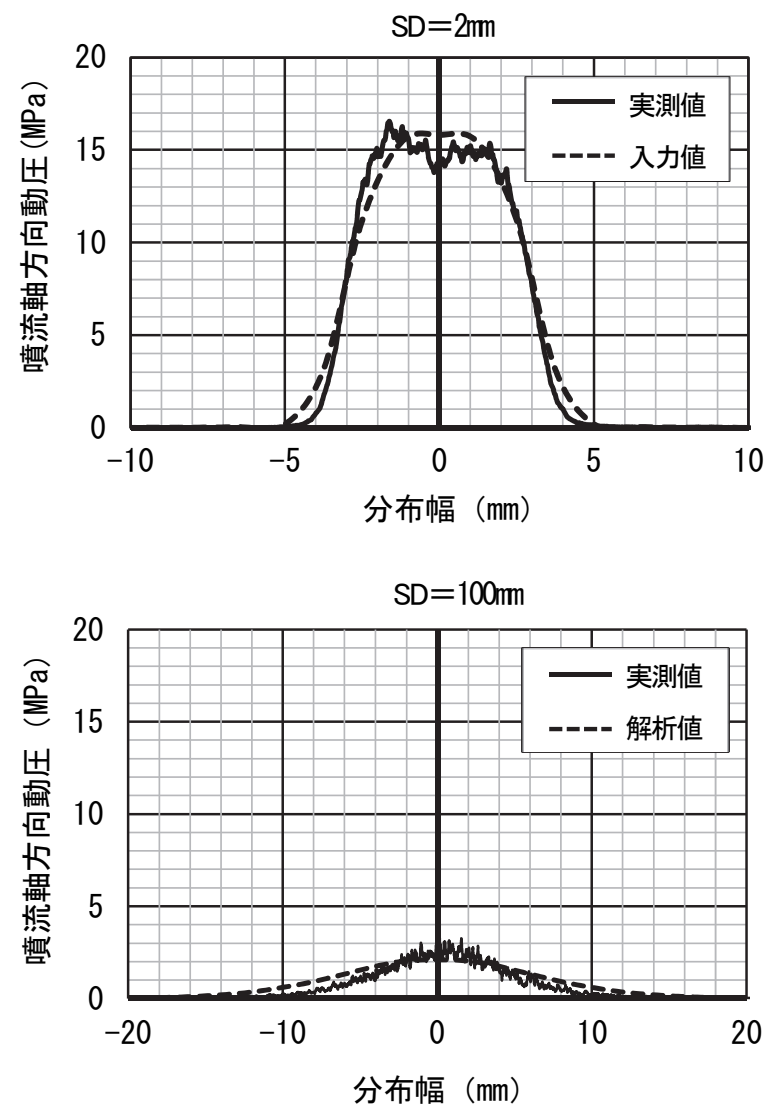

図-11 動圧分布の実測值と解析值 (D1000，L1800)
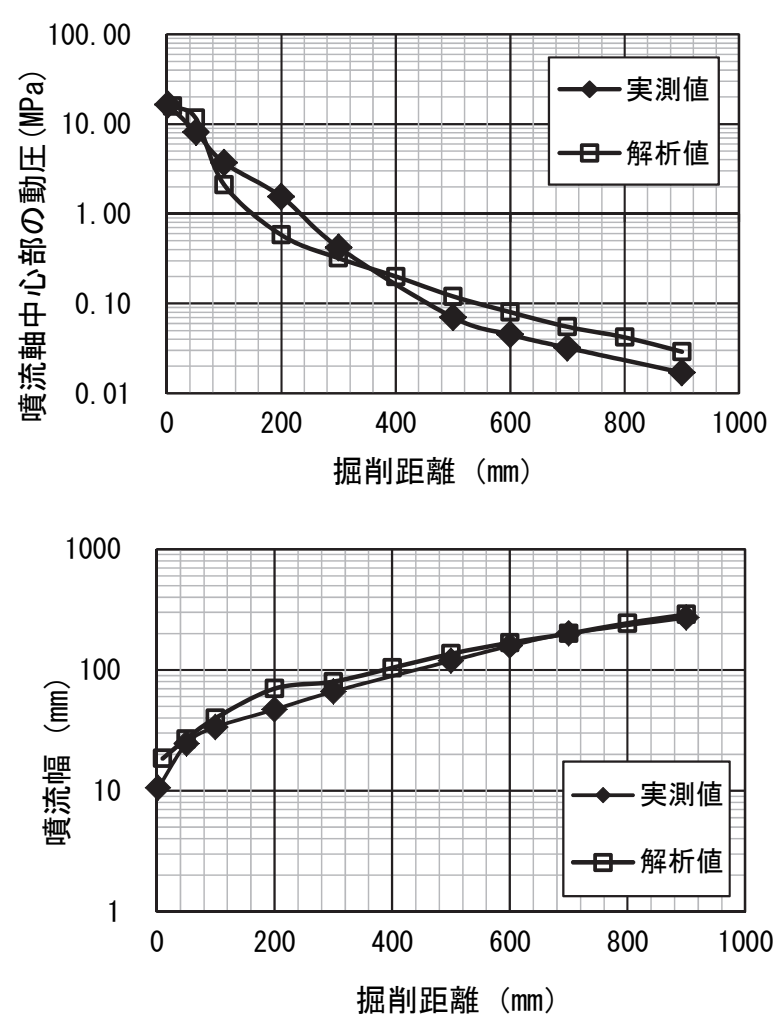

図-12 SD増加に伴う中心動圧と噴流幅の変化 (D1000, L1800)
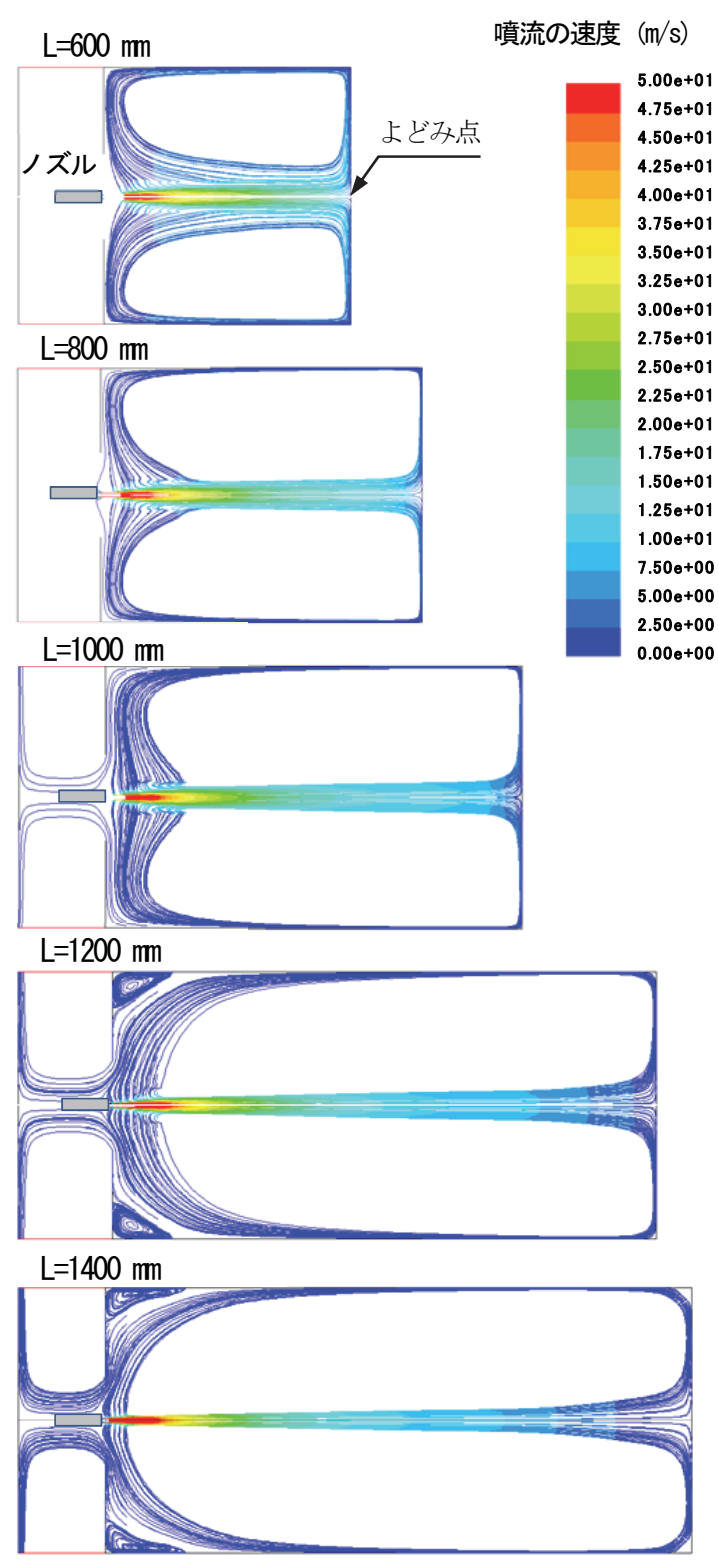

図-13 掘削の進行に伴う流体の軌跡

傍ではせき止め圧が卓越し，それ以外の部分には掃流力 が作用している. いずれの力も掘削の進行（Lの増大） にともない低下し，掘削限界に至ると推定される.

図-15 は wall-end に作用する静圧を示している。半径 $0 \mathrm{~m}$ 付近の中央部では噴流による大きな静圧が生じてお り，図-14 からも明らかなように中央部で地盤の掘削が 進行する. また, 半径の拡大にともない静圧は低下し負 圧になる．これは，wall-end における放射状の流れにと もなう現象で半径方向の慣性力と流体の連続性の維持と が絡み合って生じるためと考えられる。この流れが wall-side に接近すると，せき止められ再び静圧が上昇す る. この圧力は図-15 からも分るように，D が小さいほ ど，L が短いほど大きく，地盤の強度以上であれば，掘 
削面の周縁部が掘削されて，掘削空間の径が拡大する.

この現象は，前述の水中における噴流の動圧測定実験 のように，境界条件を考慮しない噴流の拡大とは異なり， 掘削領域の境界が作る流れと境界に作用する力により掘 削が進行することを表している.
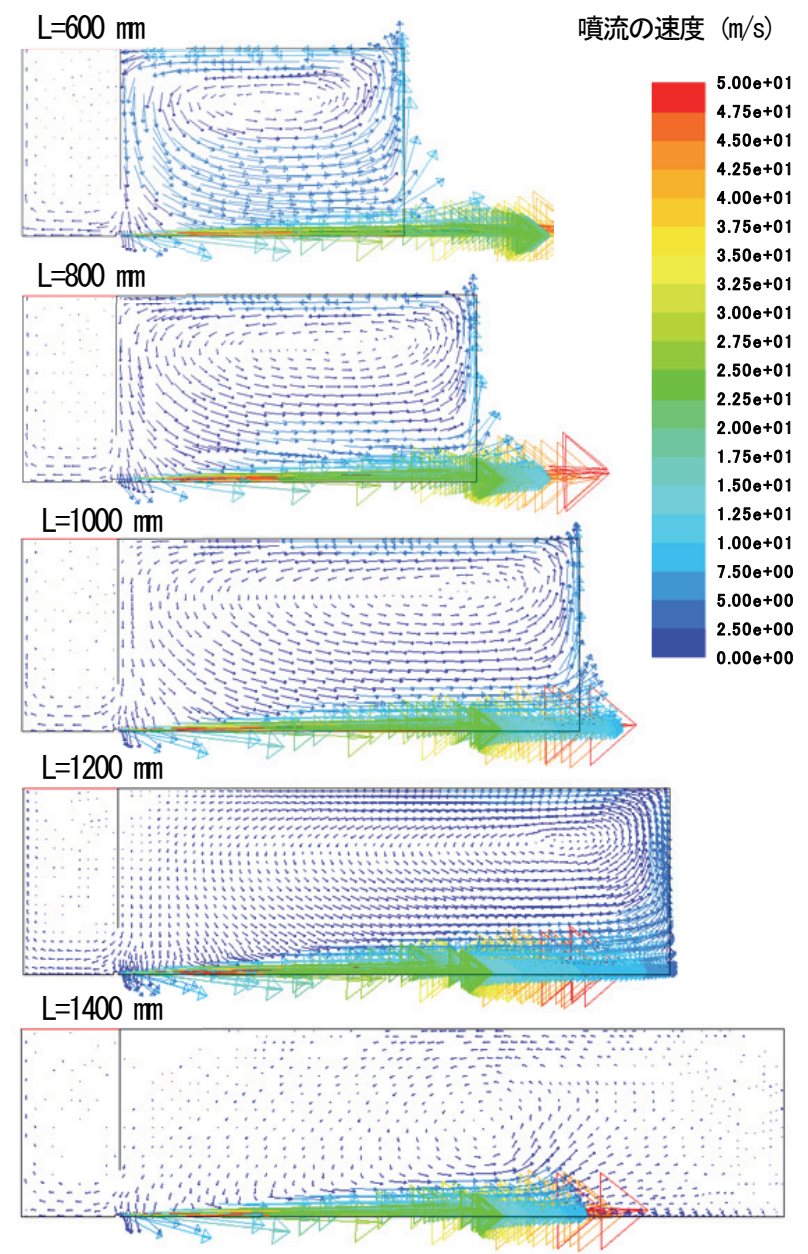

図-14＼cjkstart掘削の進行に伴う速度ベクトルの変化

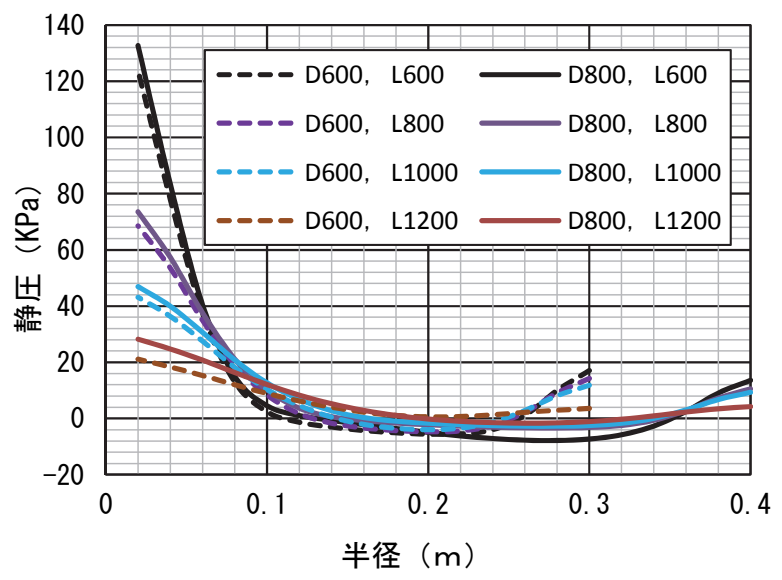

図-15 wallendに作用する静圧

\section{(3) FVM 解析のまとめ}

FVM 解析は実際の現象を精度よく表現できた。結果 として，水中に噴射された混合噴流は，周囲の水を巻き 込み噴流幅が増大すること，噴流は掘削空間内で循環す る流れを作り, 掘削領域を前方のみならず半径方向にも 拡大寸ること，その結果，ノズルを移動することなく広 範囲の地盤改良が可能となることなど，掘削領域の境界 である地盤への混合噴流の作用が明らかとなった。

\section{6. 模擬地盤の掘削実験}

\section{(1) 可視化用透明容器の製作}

これまでの動圧分布の測定結果から，ノズルを固定し て噴射した場合には，掘削径は圧力容器の径より小さく なることが予想される，そこで，掘削過程を可視化する 目的で，圧力容器内に小口径の透明なアクリル容器を装 着し，その内部に充填した模擬地盤を作り，それを超高 圧噴射を用いて掘削して，その状況を外部からビデオで 撮影することとした。 これにより掘削過程を目視するこ とができ，かつ被圧水下での実験も可能となるが，アク リル容器の適正な大きさが不明なことから，長さは $1500 \mathrm{~mm}$ とし，内径は $200 \mathrm{~mm}, 300 \mathrm{~mm}, 450 \mathrm{~mm}$ の 3 種の 容器を作成して実験を行った. 写真-5 は圧力容器内に アクリル容器を挿入している写真である.

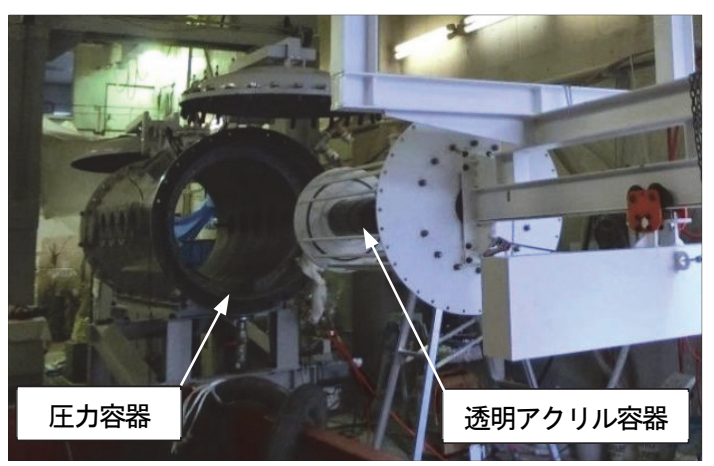

写真-5＼cjkstart透明アクリル容器設置状況

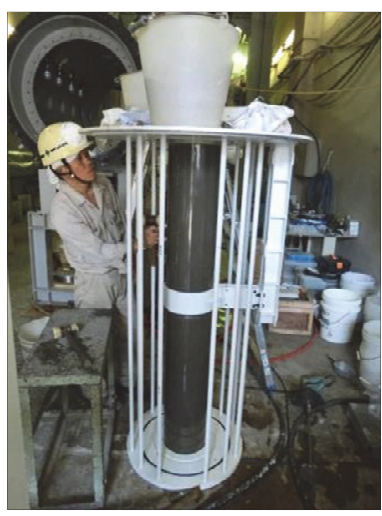

写真-6 模擬地盤の作成状況 


\section{（2）模擬地盤の作成方法}

模擬地盤は軟弱粘性土，硬質粘性土，砂質土の3 種と

し，表-3 に示した配合で作成した。このうち砂地盤は， ミキサーによる混練が困難であるため，まず，セメント ミルクを混練し，その中に砂を投入する方法で作成した. 写真-6 は模擬地盤の作成状況の写真である.

\section{（3）可視化容器を用いた掘削実験}

地盤掘削実験は 3 種類の模擬地盤に対して，表-4に示 す条件で実施した.

写真-7 は掘削前面の位置のビデオ映像である.また， 図-16 および図-17 は，粘性土地盤と砂質土地盤につい て，それぞれの噴射時間と掘削前面の位置との関係を示 したものである。これらの図には実験を行う直前に実施 した模擬地盤のモールドサンプルの一軸圧縮強さを併記 してある. 図中には掘削実験を行った模擬地盤の一軸圧 縮強さとアクリル容器の内径を示している.

図-16 および図-17 からわかるように，いずれの地盤 においても，掘削距離が $400 \mathrm{~mm}$ 程度までは高速で掘削 され，600mm 以上になるとその進行が著しく遅くなる.

表-3 模擬地盤の配合

\begin{tabular}{|c|c|c|c|c|}
\hline \multicolumn{5}{|c|}{ 軟弱粘性土地盤 ( $1 \mathrm{~m}^{3}$ あたり) } \\
\hline シリカヒューム & 水 & $\mathrm{W} / \mathrm{C}$ & ベントナイト & 計 \\
\hline $\mathrm{kg}$ & $\mathrm{kg}$ & $\%$ & $\mathrm{~kg}$ & $\mathrm{~kg}$ \\
\hline 150 & 902 & 601 & 100 & 1153 \\
\hline \multicolumn{5}{|c|}{ 硬質粘性土地盤( $1 \mathrm{~m}^{3}$ あたり) } \\
\hline シリカヒューム & 水 & $\mathrm{W} / \mathrm{C}$ & ベントナイト & 計 \\
\hline $\mathrm{kg}$ & $\mathrm{kg}$ & $\%$ & $\mathrm{~kg}$ & $\mathrm{~kg}$ \\
\hline 240 & 866 & 361 & 96 & 1202 \\
\hline \multicolumn{5}{|c|}{ 砂地盤( $1 \mathrm{~m}^{3}$ あたり) } \\
\hline シリカヒューム & 水 & $\mathrm{W} / \mathrm{C}$ & 砂(珪砂5号) & 計 \\
\hline $\mathrm{kg}$ & $\mathrm{kg}$ & $\%$ & $\mathrm{~kg}$ & $\mathrm{~kg}$ \\
\hline 116 & 387 & 334 & 1580 & 2083 \\
\hline
\end{tabular}

表-4 模擬地盤の掘削条件

\begin{tabular}{|c|c|c|c|}
\hline 項目 & 条件 & 単位 & 設定值 \\
\hline \multirow{4}{*}{ [1]AJライン } & 噴射圧カ & $\mathrm{MPa}$ & 1.0 \\
\cline { 2 - 4 } & ノズル径 & $\mathrm{mm}$ & 6.0 \\
\cline { 2 - 4 } & 噴射流量 & $\ell / \mathrm{min}$ & 68.6 \\
\cline { 2 - 4 } & 噴流速度 & $\mathrm{m} / \mathrm{s}$ & 40.5 \\
\cline { 2 - 4 } & 運動量流束 & $\mathrm{kg} \cdot \mathrm{m} / \mathrm{s}^{2}$ & 51.2 \\
\hline \multirow{4}{*}{ [2]WJライン } & 噴射圧カ & $\mathrm{MPa}$ & 220.0 \\
\cline { 2 - 4 } & ノズル径 & $\mathrm{mm}$ & 1.4 \\
\cline { 2 - 4 } & 噴射流量 & $\ell / \mathrm{min}$ & 53.6 \\
\cline { 2 - 4 } & 噴流速度 & $\mathrm{m} / \mathrm{s}$ & 663.3 \\
\cline { 2 - 4 } & 運動量流束 & $\mathrm{kg} \cdot \mathrm{m} / \mathrm{s}^{2}$ & 592.1 \\
\hline [1]+[2] & 運動量流束 & $\mathrm{kg} \cdot \mathrm{m} / \mathrm{s}^{2}$ & 643.3 \\
\hline \multicolumn{2}{|c|}{ 混合噴流の算定速度 } & $\mathrm{m} / \mathrm{s}$ & 315.2 \\
\hline
\end{tabular}

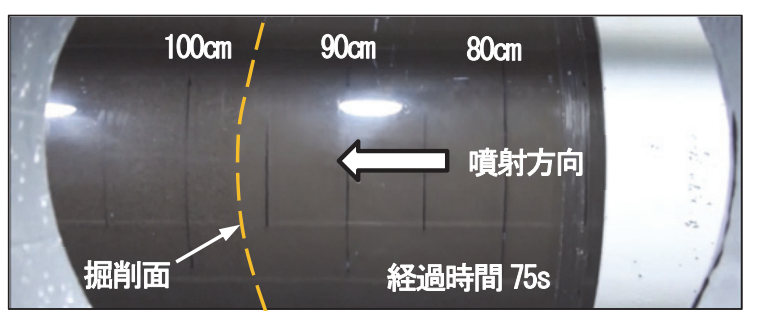

写真-7 模擬地盤の掘削状況

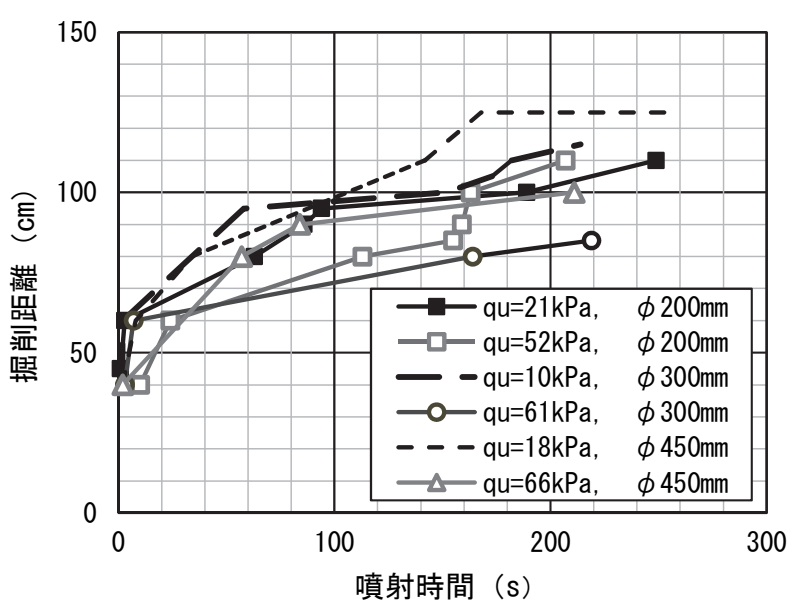

図-16 粘性土地盤の掘削距離

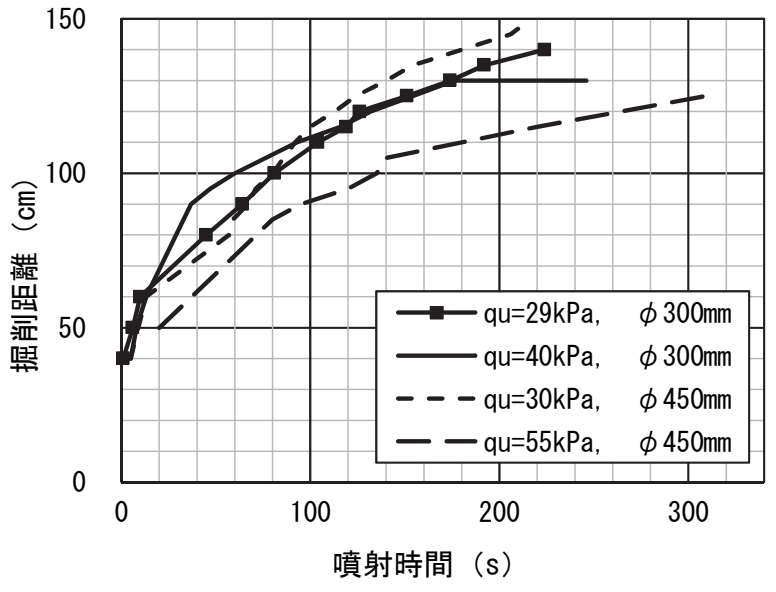

図-17 砂質土地盤の掘削距離

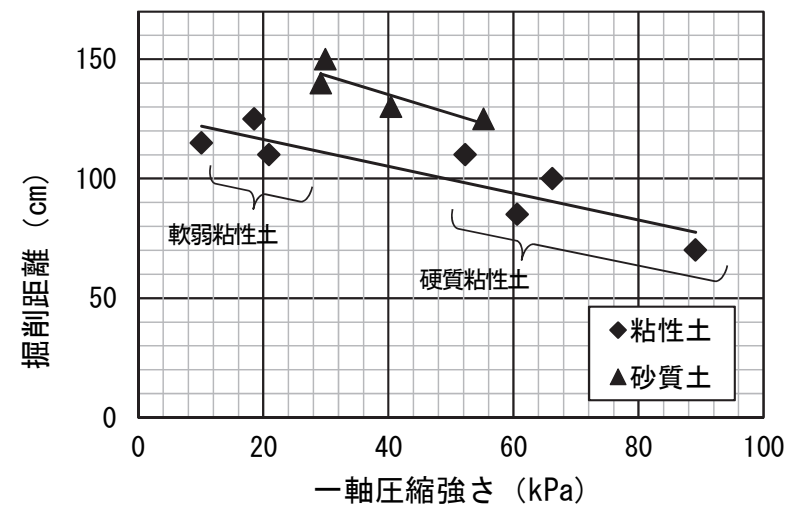

図-18 模擬地盤の強度と掘削距離 
これは図-7 の噴流軸中心部の動圧測定結果によれば, $\mathrm{SD}=400 \mathrm{~mm}$ における中心動圧は $100 \mathrm{kPa}$ 以上であり, 地 盤強度の倍以上の圧力となっている一方, $\mathrm{SD}=600 \mathrm{~mm}$ で は $45 \mathrm{kPa}$ で地盤強度と同程度となっていることによると 考えられる. 中心動圧が地盤強度以下の領域でも掘削は 進行しているが, これは流速による洗掘の結果と推測さ れる. いずれの条件でも掘削前面は，写真-7 に示すよ うに，ほぼ扁平な形状を維持しながら進行する．なお， いずれのアクリル容器の径においても, 容器の内壁に地 盤が残存することなく，外部から掘削の進行状況が観察 できたこの結果は，粘性土地盤でも砂質土地盤でも掘 削径は 450mm 以上確保されていることを示している. また, 掘進速度に対する容器の径の影響は, 地盤強度を 考慮すると明確には認められなかった.

図-18 は地盤の一軸圧縮強さと噴流の到達距離との関 係を示したものである.この図をみると，模擬地盤を作 成する際の配合は同じにしても，できあがった地盤の強 度にはかなりのバラツキがあるが，地盤の一軸圧縮強さ が高くなると，噴流の到達距離はほぼ線形で小さくなる ことがわかる．到達距離は，一軸圧縮強さが 20kPa 以下 の軟弱粘性土地盤では $120 \mathrm{~cm}$ ，一軸圧縮強さが $50 \mathrm{kPa}$ 以 上の硬質粘性土地盤では $80 \mathrm{~cm}$ から $100 \mathrm{~cm}$ ，砂質土地盤 では $130 \mathrm{~cm}$ から $150 \mathrm{~cm}$ になる。.また，粘性土地盤におけ る到達距離は，砂質土地盤と比較すると，地盤強度が同 じであっても小さい. これは粘性土地盤の粘着力による ものと判断される.

\section{7. 混相流モデルによる地盤掘削過程の FVM 解析}

地盤の掘削過程を表現するために FVM による非定常 解析を行った．表-5 はそれに用いたオイラーの混相流 モデルの解析条件を示したものである. 解析モデルのメ ッシュおよびゾーンは図-10 と同様である.このモデル は 2 種類以上の相の異なる物質の運動を扱うことができ， 例えば，河川による堆積砂の運搬などを容易に解くこと ができる.

しかし，粘性土地盤や拘束された砂地盤の掘削問題の 場合には，粘性や有効応力のモデル化が難しく，破壊現 象を扱える構造解析ソフトとの連成解析を行うという困 難に直面する，そのため，ここでは掘削過程を定性的に 捉えることに主眼を置き，地盤を高粘度の流体と砂の混 合物でモデル化して，実験結果を近似できるような粘性 係数を逆算した．粒子への運動量の伝達には，抗力係数 を用いた。

図-19 は掘削の進行状況を体積分率で表した経過時間 ごとの解析結果である．体積分率は，地盤を模擬した高 粘性流体がどの程度の割合で噴射流体に置換されたかを
示す比率で定義した。したがって，粘性流体が完全に置 換された場合には，体積分率は 1 となる。この図をみる と，噴流が地盤を掘削していく様子がよくわかる.

表-5 非定常解析条件

\begin{tabular}{|c|c|c|c|}
\hline 解析コード & \multicolumn{3}{|c|}{ ANSYS FLUENT非定常解析 } \\
\hline 座標 & \multicolumn{3}{|c|}{ 2次元軸対称 } \\
\hline 混相流モデル & \multicolumn{3}{|c|}{ Euier-Euler Model } \\
\hline time step & \multicolumn{3}{|c|}{ 1s } \\
\hline 密度 & 高粘性流体 & 砂 (粒径0.5mm) & 水 \\
\hline $\mathrm{g} / \mathrm{cm}^{3}$ & 1.46 & 2.15 & 1 \\
\hline 計算領域 & 直径 $\mathrm{mm}$ & \multicolumn{2}{|c|}{ 長さ $\mathrm{mm}$} \\
\hline D450 & 450 & \multicolumn{2}{|c|}{2500} \\
\hline $\mathrm{D} 1000$ & 1000 & \multicolumn{2}{|c|}{2500} \\
\hline
\end{tabular}

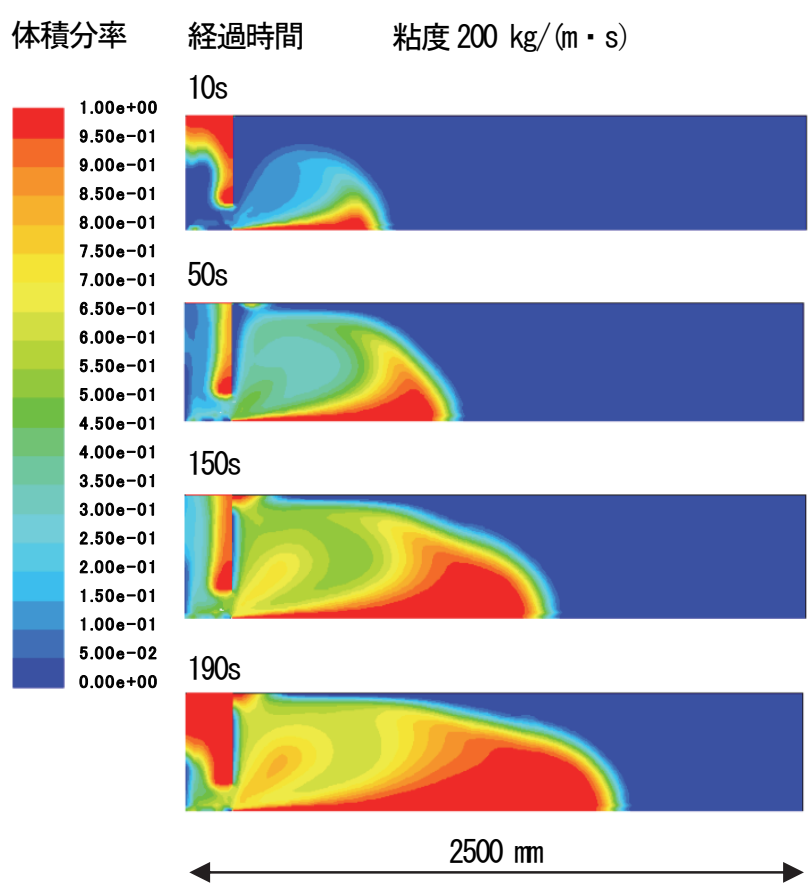

図-19 非定常解析結果（D1000）

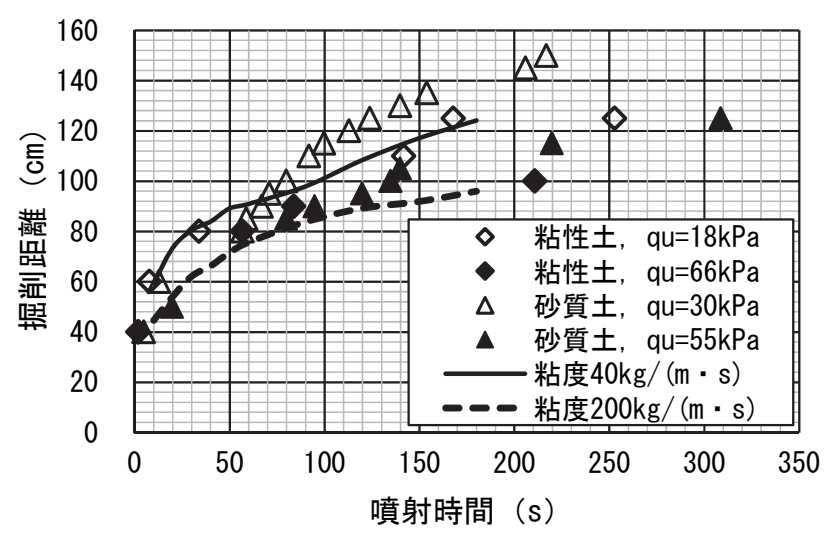

図-20 地盤掘削の解析值と実測值 
図-20 は体積分率が 95\%の場合を掘削範囲と仮定して， 掘削前面の位置の進行状況を掘削実験結果と比較したも のである.この図をみると, 解析結果は, 掘削距離の増 加とともに掘削の進行速度が低下して行く傾向を概ね表 現できており，混相流モデルは本研究のような問題にも 有効な解析手法であると思われる. 本研究では, 粘度と 地盤の種類や地盤強度との関係を定式化するには至って いないが，粘度が $40 \mathrm{~kg} /(\mathrm{m} \cdot \mathrm{s})$ から $200 \mathrm{~kg} /(\mathrm{m} \cdot \mathrm{s})$ の範 囲では，ほぼ妥当と思われる結果が得られた。

\section{8. まとめ}

本研究により得られた知見を，二液混合噴流の動圧分 布，地盤の掘削実験および FVM 解析についてまとめる と, 以下のとおりとなる.

\section{（1）二液混合噴流の動圧分布}

水中において噴射された混合噴流の動圧は，二液混合 ノズル出口から動圧測定位置までの距離 SD の増加とと もに急激に減少し， $\mathrm{SD}=100 \mathrm{~mm}$ ではノズルの出口の約 $1 / 5$ に, $\mathrm{SD}=200 \mathrm{~mm}$ では $1 / 10$ 以下になった. 一方，噴流 幅は，SD の増加とともに周囲の水を取り込み増大する。 $\mathrm{SD}=900 \mathrm{~mm}$ では噴流幅はノズルの出口付近の約 25 倍と なった. この結果は, 高速でかつ噴流径の小さな流れが, SD の増加とともに低速でかつ噴流径の大きな流れに変 化していくことを示している．地盤改良用の混合噴流は アブレシブノズルから噴出した時点で，一般の噴射式地 盤改良（ジェットグラウト等）と同程度の圧力となって おり，コンクリート構造物を損傷する可能性はない.

\section{（2）地盤の掘削実験}

砂質土，粘性土いずれの地盤の場合も，掘削面はほぼ 扁平な形状を維持しながら進行する.また，いずれの地 盤においてもノズルからの距離が $400 \mathrm{~mm}$ 程度までは高 速で掘削され，600mm 以上では掘削の進行が著しく遅 くなる.これは，400mm における中心動圧が $100 \mathrm{kPa}$ 以 上で地盤強度の倍以上あり，600 $\mathrm{mm}$ では $45 \mathrm{kPa}$ で地盤強 度と同程度となっていることによる.

到達距離は地盤強度の増加とともに低下寸るが，粘性 土地盤と砂質土地盤を比較すると，同一の地盤強度では 粘性土地盤の方が小さい. 到達距離は, 軟弱な粘性土地 盤では $120 \mathrm{~cm}$ ，硬質な粘性土地盤では $80 \mathrm{~cm}$ から $100 \mathrm{~cm}$, 砂質土地盤では $130 \mathrm{~cm}$ から 150cmになる.

\section{(3) FVM 解析}

動圧分布の解析值と実測值はほぼ一致した。噴流の流 れは前方の壁に衝突し，半径方向に広がり，容器の内壁
に沿って戻る：このとき，掘削前面の中央部のみならず 周縁部にも静圧が発生する。この圧力により掘削径が拡 大する一方, 圧力は掘削距離が増加し, 掘削径が拡大す ると，それにともない低下する。

また，地盤の掘削現象は，地盤を高い粘度をもつ流体 に置き換えることにより，オイラーの混相流モデルを用 いて表現することができる.

\section{9. おわりに}

本研究で得られた知見は，二液混合噴流を用いた支障 物撤去型掘進工法の実工事適用にあたり，混合ノズルの 効率化, 改良範囲の推定, 近接構造物への影響の評価な どに活用できるものと考えている.

また，現状では動圧分布などの地盤中の挙動や改良範 囲について施工中の計測が困難なものの，今後は計測機 器の開発を含め, 本工法による施工現場での計測および 計測データと本研究との比較を研究課題として取り組み, 本工法の安全性及び施工性の一層の向上を図っていく所 存である.

謝辞 : 本研究をまとめるにあたつて，貴重なご助言を賜 った東京都下水道サービス株式会社の高橋良文氏，岩佐 行利氏に心から感謝の意を表する次第である.

\section{参考文献}

1) 宇田川孝之, 吉川静雄, 船越誠, 田村憲 : アブレシ ブジェット水流で地中障害物を切断除去し推進 東京 都下水道 第二十二社幹線暫定貯留切替推進工事, 卜 ンネルと地下, Vol. 37, No. 10, pp. 29-35, 2006.

2) 高橋智, 船橋信行：「DO-Jet 工法」による地中障害 物撤去及び地盤改良の安全で効率的な施工事例, 日 本下水道協会 45 回下水道研究発表会講演集, pp. 524526, 2008.

3) 家壽田昌司, 千葉正孝, 北原淳：既設下水道幹線直 下の残置鋼矢板を DO-Jet 工法で切断撤去 東京都下水 道 王子西一号幹線シールド, トンネルと地下, Vol. 41, No. 6, pp. 41-48, 2010.

4) 家壽田昌司, 千葉正孝, 高谷圭吾 : 地下鉄駅直下の 残置杭を DO-Jet 工法で切断撤去 東京都下水道 東大 島幹線および南大島幹線, トンネルと地下, Vol. 42, No. 2, pp. 41-47, 2011.

5）武山信幸, 中條明彦, 川元克哉：DO-Jet 工法による 既設下水道管の防護および基礎杭の切断・除去 東京 下水道 新宿区河田町 市谷本村町付近再構築, トンネ ルと地下, Vol. 47, No. 3, pp. 19-24, 2016.

6) 岡本順, 神山守, 坂本久之：地中支障物対策を駆使 したシールド施工 東京下水道 王子西一号幹線, トン ネルと地下, Vol. 47, No. 8, pp. 59-67, 2016.

7) 高橋智, 船橋信行 : DO-Jet 工法が周辺地盤に与える 影響についての実験報告, 日本下水道協会 46 回下水 道研究発表会講演集, pp. 497-499, 2009. 
8) 神山守, 磯部隆寿, 岩佐行利, 小泉淳 : DO-Jet 工法 における超高圧 2 液混合ジェット噴流の影響範囲に 関する実験的研究，トンネルと地下, Vol. 47, No. 11, pp. 47-52, 2016.

9) 日本ジェットグラウト協会 : ジェットグラウト工法 技術資料，pp. 72, 2016.

10) 土木学会：コンクリート標準示方書 設計編, pp. 32, 2012.

(2017. 5. 19 受付)

\title{
STUDY ON THE CHARACTERISTICS OF DUAL-FLUID JETS IN GROUND EXCAVATIONS INVOLVING OBSTACLE-REMOVING PIPE JACKING METHOD FOR GROUND IMPROVEMENT
}

\author{
Mamoru KAMIYAMA, Atsushi KOIZUMI, Takahisa ISOBE, \\ Masahiko TANAKA and Yohei SHIMURA
}

Widely applied in various projects, this method employs a dual-fluid, ultra-high pressure jet system mounted on an excavator typically used for pipe jacking and shield methods to shear and remove underground obstacles and for ground improvement. While the influences and range of the dual-fluid jets on the surrounding ground have been ascertained through empirical studies, difficulties in performing measurements during excavation have impeded efforts to date to clarify the range of such influences on nearby structures.

This paper attempts to clarify the characteristics of the dual-fluid jet demonstrated during ground excavation by measuring the jet's dynamic pressure and based on observations and FVM analysis (Finite Volume Method) of the excavation processes using a model of the ground. The paper offers numerical grounds for predicting the jet's influence range.

The study led to a number of conclusions: the jet's dynamic pressure immediately after it is injected from the nozzle falls short of the threshold pressure that would pose a risk of damage to nearby structures; the jet's ground excavation processes and flow characteristics within the excavation area can be accurately simulated via FVM analysis. 